The Joint Editors

The Fournal of the Institute of

20 March I95I

Actuaries Students' Society

Sirs,

\title{
Fecklin's paper on year-of-entry grouping for valuation of endowment policies
}

In his paper on year-of-entry grouping for valuation of endowment policies (F.S.S. $\mathrm{x}$, I I9) H. Jecklin utilizes the interesting approximate relationship

$$
\frac{t / n}{\mathrm{I}-t / n} \div \mathrm{F} \frac{{ }_{t} \mathrm{~V}_{x: \pi}}{\mathrm{I}-{ }_{i} \mathrm{~V}_{x: n]}}
$$

where $\mathrm{F}$ is independent of $t$. It is worth noting that, if instead of the proportionate paid-up policy $t / n$, the true paid-up policy ${ }_{t} \mathrm{~W}_{x: n}$ is used, we have the exact relationship

$$
\frac{{ }_{t} \mathrm{~W}_{x: \bar{n}}}{\mathrm{I}-\mathrm{W}_{\boldsymbol{t}} \mathrm{W}_{x: \bar{\pi}}}=\mathrm{F}^{\prime} \frac{{ }_{t} \mathrm{~V}_{x: \bar{n}}}{\mathrm{I}-{ }_{t} \mathrm{~V}_{x: \pi}} \text {, where } \mathrm{F}^{\prime}=\frac{\mathrm{I}}{\mathrm{A}_{x: \bar{n}}} \text {. }
$$

For sinking fund policies and endowment assurances at the younger ages it will be found that $\left(F^{\prime}-1\right)$ approximates to twice $(\mathrm{F}-\mathrm{I})$. The near constancy of $\mathrm{F}$ for variations in $t(x$ and $n$ fixed) suggests that in practice an $\mathrm{F}$ formula might well be a useful instrument for linking surrender values and paid-up policies by a suitable choice of a set of F's, whether the paid-up policy is on the proportionate basis or not or whether the surrender value is obtained from the paid-up policy or vice versa.

For this purpose, as well as for Jecklin's original purpose of expressing $t_{x: n}$ in terms of $\mathrm{F}$ and $t / n$ in an ingenious year-ofentry approximate valuation system, it is desirable to examine the closeness of the $\mathrm{F}$-approximation at the older ages-Jecklin gives figures at $3 \%$ on the A 1924-29 ultimate table for entry age 30 only. Figures for other entry ages are shown in Table $I$ as well as for sinking fund policies. This table confirms that $F-I$ is nearly constant and approximates to $\frac{1}{2}\left(\mathrm{~F}^{\prime}-1\right)$ for ages at maturity up to 60 ; thereafter, the approximation progressively breaks down.

It does not necessarily follow, however, that even in these cases 
the assumption of a constant value for $\mathrm{F}$ will produce an intolerable approximation for ${ }_{i} V_{x: \bar{n} \mid}$ or a worse result than by assuming a common maturity age of, say, 6o. An extreme example is given in Table 2.

Table $\mathrm{I}$. Values of $(\mathrm{F}-\mathrm{I})$ and $\left(\mathrm{F}^{\prime}-\mathrm{I}\right)$ for $3 \%$ sinking fund policies and for endowment assurances on A 1924-29 ult. $3 \%$

\begin{tabular}{|c|c|c|c|c|c|c|c|c|}
\hline \multirow{2}{*}{ Term } & \multirow{2}{*}{ Duration } & \multirow{2}{*}{$\begin{array}{l}\text { Sinking } \\
\text { fund }\end{array}$} & \multicolumn{6}{|c|}{ Age at entry } \\
\hline & & & 20 & 30 & 40 & 50 & 60 & 65 \\
\hline 10 & $\begin{array}{cc}\text { All } & F^{\prime}-I \\
\text { I } & F-I \\
5 & \\
9 & \end{array}$ & $\begin{array}{l}\cdot 344 \\
\cdot 163 \\
\cdot 159 \\
\cdot 156\end{array}$ & $\begin{array}{r}\cdot 339 \\
\cdot 176 \\
\cdot 173 \\
\cdot 169\end{array}$ & $\begin{array}{r}\cdot 339 \\
\cdot 176 \\
\cdot 172 \\
\cdot 171\end{array}$ & $\begin{array}{l}\cdot 335 \\
\cdot 181 \\
\cdot 182 \\
\cdot 182\end{array}$ & $\begin{array}{l}-325 \\
\cdot 191 \\
\cdot 200 \\
\cdot 211\end{array}$ & $\begin{array}{r}.298 \\
.237 \\
.266 \\
.307\end{array}$ & $\begin{array}{r}.273 \\
.271 \\
\cdot 332 \\
.412\end{array}$ \\
\hline 20 & $\begin{array}{rl}\text { All } & F^{\prime}-I \\
1 & F-I \\
5 & \\
10 & \\
19 & \end{array}$ & $\begin{array}{r}\cdot 806 \\
\cdot 362 \\
\cdot 354 \\
\cdot 344 \\
\cdot 327\end{array}$ & $\begin{array}{l}777 \\
\cdot 397 \\
\cdot 386 \\
\cdot 374 \\
\cdot 356\end{array}$ & $\begin{array}{l}768 \\
\cdot 381 \\
\cdot 373 \\
\cdot 367 \\
\cdot 364\end{array}$ & $\begin{array}{r}\cdot 737 \\
\cdot 370 \\
\cdot 371 \\
\cdot 374 \\
\cdot 399\end{array}$ & $\begin{array}{l}.659 \\
\cdot 325 \\
\cdot 338 \\
.371 \\
.505\end{array}$ & $\begin{array}{r}.501 \\
\cdot 234 \\
\cdot 277 \\
.378 \\
.817\end{array}$ & $\begin{array}{l}- \\
- \\
- \\
-\end{array}$ \\
\hline 25 & $\begin{array}{rl}\text { All } F^{\prime}-\text { I } \\
1 & F-I \\
5 & \\
10 & \\
20 & \\
24 & \end{array}$ & $\begin{array}{r}I \cdot 094 \\
\cdot 479 \\
\cdot 467 \\
\cdot 454 \\
\cdot 427 \\
\cdot 418\end{array}$ & $\begin{array}{r}x \cdot 036 \\
\cdot 519 \\
\cdot 507 \\
\cdot 490 \\
\cdot 463 \\
\cdot 456\end{array}$ & $\begin{array}{r}r \cdot 014 \\
\cdot 490 \\
\cdot 478 \\
\cdot 471 \\
\cdot 468 \\
\cdot 475\end{array}$ & $\begin{array}{l}\cdot 944 \\
\cdot 446 \\
\cdot 445 \\
\cdot 446 \\
\cdot 488 \\
\cdot 532\end{array}$ & $\begin{array}{l}\cdot 788 \\
\cdot 316 \\
\cdot 326 \\
\cdot 359 \\
\cdot 542 \\
.699\end{array}$ & $\begin{array}{l}- \\
- \\
- \\
-\end{array}$ & $\begin{array}{l}- \\
- \\
- \\
-\end{array}$ \\
\hline 30 & $\begin{array}{rl}\text { All } & F^{\prime}-I \\
I & F-I \\
5 & \\
10 & \\
20 & \\
29 & \end{array}$ & $\begin{array}{r}r \cdot 427 \\
\cdot 608 \\
\cdot 592 \\
\cdot 575 \\
\cdot 541 \\
\cdot 510\end{array}$ & $\begin{array}{r}r \cdot 321 \\
.656 \\
.637 \\
.613 \\
.577 \\
.565\end{array}$ & $\begin{array}{c}1 \cdot 272 \\
\cdot 584 \\
\cdot 576 \\
\cdot 565 \\
\cdot 563 \\
\cdot 59 x\end{array}$ & $\begin{array}{r}r \cdot 133 \\
\cdot 491 \\
\cdot 482 \\
\cdot 479 \\
\cdot 522 \\
.681\end{array}$ & $\begin{array}{l}\cdot 872 \\
\cdot 243 \\
\cdot 244 \\
\cdot 264 \\
\cdot 420 \\
.933\end{array}$ & $\begin{array}{l}- \\
- \\
-\end{array}$ & $\begin{array}{l}- \\
- \\
-\end{array}$ \\
\hline 40 & $\begin{aligned} \text { All } F^{\prime}-1 \\
1 F-1 \\
5 \\
20 \\
39\end{aligned}$ & $\begin{array}{r}2 \cdot 262 \\
.902 \\
.886 \\
.806 \\
\cdot 710\end{array}$ & $\begin{array}{r}1 \cdot 943 \\
\cdot 932 \\
\cdot 898 \\
\cdot 799 \\
\cdot 799\end{array}$ & $\begin{array}{r}1 \cdot 756 \\
\cdot 719 \\
.693 \\
.655 \\
.868\end{array}$ & $\begin{array}{r}x \cdot 380 \\
\cdot 407 \\
\cdot 385 \\
\cdot 356 \\
x \cdot 06 r\end{array}$ & $\begin{array}{l}- \\
- \\
-\end{array}$ & $\begin{array}{c}- \\
- \\
-\end{array}$ & - \\
\hline
\end{tabular}

From a practical point of view, Jecklin's approximate valuation method is subject to the serious drawback that, as presented so far, it does not enable us to obtain any valuation figures other than the total of the policy values. In British practice we also need the value of the sums assured, the value of the net premiums and the amount of the net premiums. For with-profits 
policies we also need the value of the accrued bonuses; the value of the sums assured is also required to obtain the value of the new bonus. Most of these drawbacks would appear also to apply to the retrospective $t$-method studied recently in Switzerland and referred to in Jecklin's paper.

Table 2. Specimen values of $(\mathrm{F}-\mathrm{I})$ and ${ }_{t} \mathrm{~V}_{x: \bar{n}}$ and approximate values of ${ }_{i} \mathrm{~V}_{x: \text { i }}$ based on a constant value of $(\mathrm{F}-\mathrm{I})$ for an endowment assurance at entry age 40, term 35 years on A 192429 ult. $3 \%$. Policy values for maturity age 60 are also shown.

\begin{tabular}{|c|c|c|c|c|c|}
\hline$t$ & $F-I$ & ${ }_{t} \mathrm{~V}_{x: \bar{n}}$ & $\begin{array}{c}\text { Approx.* } \\
{ }_{t} \mathrm{~V}_{x: n}\end{array}$ & $\begin{array}{l}\text { Percentage } \\
\text { error }\end{array}$ & ${ }_{t} \mathrm{~V}_{25: 357}$ \\
\hline I & $\cdot 471$ & 1.96 & $x \cdot 95$ & -.5 & $I \cdot 66$ \\
\hline 5 & $\cdot 463$ & $10 \cdot 23$ & 10.12 & $-I \cdot I$ & $8 \cdot 82$ \\
\hline 10 & 452 & $21 \cdot 60$ & $21 \cdot 28$ & $-I \cdot 5$ & 19.09 \\
\hline I 5 & .454 & 34.03 & $33 \cdot 63$ & $-1 \cdot 2$ & 30.89 \\
\hline 20 & 480 & $47 \cdot 40$ & $47 \cdot 39$ & - & 44.41 \\
\hline 25 & $\cdot 545$ & $6 I \cdot 80$ & $62 \cdot 81$ & $+1 \cdot 6$ & 60.01 \\
\hline 30 & .675 & $78 \cdot 18$ & $80 \cdot 21$ & $+2 \cdot 6$ & $78 \cdot 19$ \\
\hline 34 & .857 & $94 \cdot 82$ & $95 \cdot 83$ & $+I \cdot I$ & $95 \cdot 26$ \\
\hline
\end{tabular}

* Note. The approximate values of ${ }_{t} \mathrm{~V}_{x: \bar{n}}$ are obtained from the formula ${ }_{t} \mathrm{~V}_{x: \bar{n}]}=t /[t+\mathrm{F}(n-t)]$ with $\mathrm{F}=\mathrm{I} \cdot 48$.

It is perhaps not inappropriate, therefore, to refer to the fact that in my first paper on the $n$-point method (F.I.A. LXrv, 264) I gave a method of valuing endowment assurances in year-of-entry groupings which yields all the desired figures. This method requires the assumption of a fixed maturity age. In my second paper on the $n$-point method ( $\mathcal{H} . I . A$. LxxII, 377) I gave methods which could readily be adapted to year-of-entry groupings in which both variables $x$ and $n$ could be allowed for together, if for some reason a fixed maturity age could not be adopted. The $n$-point method also has the great advantage that it frees the classification from any particular valuation basis.

Yours faithfully,

WILFRED PERKS

252 High Holborn,

London, W.C. I 